UDC 331.101 .262

DOI: https://doi.org/10.37320/2415-3583/15.8

Zaika Svitlana

Candidate of Economic Sciences, Associate Professor Kharkiv Petro Vasylenko National Technical University of Agriculture ORCID: https://orcid.org/0000-0001-8132-7643

Kuskova Svitlana

Candidate of Economic Sciences, Associate Professor Kharkiv Petro Vasylenko National Technical University of Agriculture ORCID: https://orcid.org/0000-0002-4725-3537

Zaika Olena

Student

Kharkiv Petro Vasylenko National Technical University of Agriculture ORCID: https://orcid.org/0000-0002-7921-3273

\title{
THE ESSENCE AND PROBLEMS OF MOTIVATION AS A FACTOR IN THE DEVELOPMENT OF MODERN ENTERPRISES
}

Motivation of employees of the enterprise is a determining factor in ensuring its effective development, because thanks to the employees having a desire to work with dedication, growing interest in the effectiveness of the results of joint work. The purpose of the study was to substantiate the theoretical aspects of improving the management of the motivation of employees of the modern innovative enterprises. The study of the motivation system indicated that the most problematic issue was to identify motivational factors that may affect the productivity of modern enterprises. It was established that motivational tools for modern innovative enterprises can differ significantly. Therefore, to ensure sustainable development and increase the level of competitiveness of enterprises, management needs to pay considerable attention to the management of employee motivation and its features specific to a particular sector of the national economy.

Key words: motivation, enterprise personnel, motivation management, motivating factors, modern innovative enterprises.

JEL classification: J01, J24, J30, M50 
Formulation of the problem. Since the middle of the last century, the motivation of employees is one of the most important functions of management, while the problems of motivation and incentives for employees still occupy a significant place in the management of enterprises. In addition, today there is a significant difference in the motivation of staff of different types of enterprises, which cannot but affect the forms, methods and tools of motivation. At the same time, the emergence of new forms of business requires the development of new relationships between employees and employers, which is reflected in the management of the motivation of employees, which must take into account the specifics of a particular type of enterprise.

Currently, the main feature of the functioning of personnel in enterprises is a significant component of creative, scientific and educational activities. This specificity is a source of difficulties in managing motivation in modern enterprises, as employees who form the basis of such enterprises, as a rule, have atypical motives for work. In addition to the fact that modern enterprises have their own specifics for the formation of motivation systems, within this type of activity there is also a significant differentiation of the level of the motivation of employees, which determines the set of motivational tools.

Thus, improving the process of managing the motivation of employees in modern innovative enterprises is an urgent task, both from a theoretical and practical point of view.

Analysis of recent research and publications. Studies of a number of domestic and foreign scientists, who in their works focus on the general principles of formation and management of motivation, without studying its specifics, which arises in the functioning of motivation systems in modern innovative enterprises, are devoted to the issue of personnel motivation management.

Issues of development of modern enterprises were studied in the works of Ukrainian researchers, but they did not pay enough attention to the peculiarities of the personnel motivation management in modern innovative enterprises.

Such scientists as Boyko Yu., Bondar V., Korobkina M., Kolot A., Kulipanov K., Maznev G., Ustilovska A. and many others dealt with the issues of the motivation of employees. At the same time, these authors did not pay enough attention to systematizing the characteristics of the motivation of employees of modern innovative enterprises.

Thus, despite the fact that at present research covers a wide range of aspects of the problem, and has already obtained scientific results, both theoretical and applied, the issues related to the management of the motivation of employees of modern innovative enterprises type still remain unexplored. The above necessitates research in the field of improving the management of motivation of modern enterprises with innovative development.

The purpose of the article is to substantiate the theoretical provisions for improving the process of managing the motivation of personnel of modern enterprises.

Presenting main material. The process of enterprise management is impossible without the competent motivation of employees to achieve the goals set in the planning. This is true for all types of enterprises and is crucial for situations where the human factor directly affects the outcome. The problem of the motivation of employees has been one of the central ones in management for at least seventy years.
In the middle of the last century, scientists who dealt with the problems of management and its efficiency, focused on the factors that have a motivating and demotivating effect on the employee. Since then, management has increasingly been seen as the art of managing people. By the end of the last century, different motivational theories began to form a single concept, which provides an individual approach to employees, different methods of motivation, which depend on the scope of the enterprise and its scale, as well as mentality and cultural traditions. The simple statement of the fact that staff need to be motivated by both tangible and intangible methods and even the formation of various incentives have ceased to satisfy managers who seek to improve the efficiency of the personnel management process.

According to scientists, motivation is a set of internal and external driving forces that motivate a person to activity, determine his or her behavior, forms of activity, and give this activity a focus on achieving personal goals and goals of the enterprise [15].

Need is a basic element of the motivational process; according to some scientists, it is defined as the need for any benefits to support the life and development of man and society as a whole $[3 ; 5 ; 9]$.

The next important term is motive. Motive is the motivating causes of behavior and actions that develop under the influence of human needs and interests [8].

In order for the need to become a motive, a certain stimulus is needed. Incentive is an external impulse, external cause and motivation to act [5].

In this case, motivation is a multifaceted phenomenon that must be disclosed from different angles and points of view, so given the terms already considered, motivation is a set of all motives that currently have a significant impact on employees, and therefore it provides for the impact on specific needs of employees through specific incentives. Thus, we approach the formation of a motivational mechanism.

The motivational mechanism is a complex process that includes the stages of interaction of the subject and the object of management through motivational influences that transform personal interests, values and priorities into team goals. The result of its action is the satisfaction of the subject and the object of management, which becomes possible if the effect obtained from motivation (estimated by the subject) corresponds to the level of remuneration of the object.

Accordingly, it is necessary to disclose another term reward. Remuneration, according to some authors, is a tangible or intangible benefit provided by the employee after the necessary actions to achieve a specific result and affects the satisfaction of the object of motivational influences [14].

The motivational mechanism takes place in the system of work motivation, which is a set of tools and methods aimed at motivating and stimulating employees to organize a positive business process and achieve business goals [1;12].

The essence of the motivational structure is that in the enterprise there may be several motivational types at the same time. In addition, usually each employee is not an ideal motivational type, but combines several types in different proportions. This situation affects the effectiveness of motivation of a group of employees, as well as individual motivation. The study of motivational structure is necessary to identify the most effective motivational tools for certain 
motivational types. The result of the competent use of the motivational structure is to increase productivity, improve the microclimate in the team and, as a consequence, increase the level of efficiency of the enterprise as a whole.

Thus, in our opinion, the motivational structure is a set of logically related motives that reflect the motivational profile of the individual or enterprise. Thus the motivational profile represents an individual combination of motivating factors of the person or the enterprise [8; 11].

Consider the systems of motivational types that are currently used. The first attempt to determine motivational profiles was made by staff training instructors S. Richie and P. Martin [16]. At the same time, the profiles themselves were not selected; the authors limited themselves to the selection of twelve factors, including certain motivational components, which in a certain combination influenced the tools to stimulate employees:

- high earnings - the need associated with high income, material rewards and material goods;

- comfort - the need associated with the need to work in comfortable physical conditions;

- structuring of work - the need associated with the need to have feedback and information about their work, with a decrease in the degree of uncertainty that is directly related to work;

- social contacts - the need associated with social contacts: at the level of easy communication with a wide range of people;

- relationships - the need to establish a stable long-term relationship: close relationships with a small group of people;

- recognition - the need associated with the recognition of merit and the establishment of feedback (feedback on their work): the acquisition of social significance;

- the pursuit of achievement - the need associated with the achievement and setting bold personal goals;

- influence and control - the need associated with the acquisition of influence and the establishment of control over others;

- diversity and change - the need associated with the need for diversity and breaks, i.e. the desire to constantly feel the stimulating interest;

- creativity - the need associated with curiosity, creativity and breadth of views;

- independence - the need associated with independence and self-improvement of the personality;

- interesting work - a need associated from the beginning with useful and grateful work for society.

On the basis of these factors, a survey of employees of the enterprise, during which they answer questions related to their professional activities and personal preferences. The questionnaires are then processed according to the key and employees are divided into motivational groups, which are then influenced by various motivational tools. This technique is very popular; it is used in some countries to manage the motivation of the employees to work. Its disadvantage is that it does not provide average values, this technique can be applied to a particular company, but the strategy of managing the motivation of certain groups of staff for different companies in the same field can not be built on its results. That is why it is used mainly as a practical tool and is rarely used in research.

With such information, the manager can understand the motives of the employee, his behavior and expectations for work. In this case, it is necessary to provide normal working conditions (equipped workplace that allows the employee to perform all tasks), a favorable psychological climate, the ability to contact and share information with managers and colleagues, as well as create conditions for numerous contacts or promotions. In addition, the manager should use different ways of recognizing the merits of the employee: from verbal gratitude to material encouragement; provide independence in work and encourage innovation; provide opportunities for professional and personal development.

In this way, motivational profiles can be built for all employees of the enterprise. Next, it is necessary to analyze these profiles and develop a motivational program focused on meeting the needs of employees. However, developing such a program is not an easy task.

The difficulty may lie in the great variety and dissimilarity of motivational profiles. In this situation, in our opinion, the following options are possible:

1. If personnel management is based on an individual approach (for small teams), the manager can analyze the motivational profile of each employee and apply the recommendations of S. Richie and P. Martin [16] to meet the most important needs of the employee in the work process.

2. If the individual approach is difficult to apply due to too large a difference in the structure of needs (for large teams), you should either build a generalized profile based on a weighted average assessment or identify key people in the company and build motivational profiles for them.

Under the key employees understand:

- employees who make a significant contribution to the value of the enterprise at the moment;

- employees who provide business development: maintaining or creating added value in the longer term [2;14].

When developing recommendations to meet the needs of key employees, it is important to identify those areas of work organization that are outside the area of influence of personnel managers: working conditions, workplace equipment, remuneration system, etc. Therefore, all recommendations can be divided into two groups:

- relating to personnel work;

- those which are outside the area of competence of HR-managers.

Thus, before selecting the forms and methods of activating the work of staff, HR-manager must enlist the support of managers of various functional areas.

It is possible to increase job satisfaction and the level of motivation of the personnel of the enterprises in modern conditions of managing only in the case when the principle of orientation on needs of employees will be put in a basis of development of motivational programs. To implement this task, the authors proposed an approach aimed at developing a motivational program, which consists in identifying, analyzing and meeting the basic needs of employees.

Conclusions. Studies of the motivational sphere show that the most significant problem is the identification of situational motivating factors that can increase the productivity of employees in various fields. At present, it is established that motivational tools and mechanisms for organizations in different industries can have serious differences in effectiveness. This leads to the fact that for its development and increase the level of competitiveness, the company's management must pay attention to the management of employee motivation and its specific features specific to this area of activity. 


\section{References:}

1. Zaika Svitlana, Gridin Oleksandr, Kuskova Svitlana (2020) The concepts and the essence of intellectual capital. Professional scientific and practical journal "Black Sea Economic Studies", vol. 52/2020, pp. 28-39.

2. Zaika S., Gridin O. (2020) Human capital development in the agricultural economy sector. Technology audit and production reserves, no. 1/4(51), pp. 30-36. DOI: 10.15587/2312-8372.2020.194444 Available at: http://journals.uran.ua/tarp/article/view/194444 (accessed 20 November 2020).

3. Boiko Yu.Y., Korobkyna M.A. (2016) Motivatsiya i stimulirovaniye truda kak obyektivnyy faktor povysheniya konkurentosposobnosti predpriyatiya $\mathrm{v}$ usloviyakh stanovleniya i razvitiya rynochnykh otnosheniy [Motivation and stimulation of labor as an objective factor in increasing the competitiveness of an enterprise in the conditions of the formation and development of market relations]. Scientific-methodical electronic journal "Concept", vol. 2, pp. 236-240. Available at: http://e-koncept.ru/2016/46061.htm (accessed 20 November 2020).

4. Bondar V. (2010) Evoliutsiia motyvatsii yak funktsii upravlinnia [Evolution of motivation as a function of management]. Naukovi zapysky. Seriia «Kultura ta sotsialni komunikatsii» [Proceedings. Culture and Social Communications Series] (eds. Ph.D., Associate Professor L.V. Kvasiuk). Ostroh: Vydavnytstvo Natsionalnoho universytetu «Ostrozka akademiia» [Ostroh Academy National University Publishing House], vol. 2, pp. 175-185.

5.Zaika S.O. (2018) Motyvatsiia ta stymuliuvannia yak chynnyky`zabezpechennia stiikogo rozvytku silskohospodarskykh pidpryiemstv [Motivation and incentives as factors in ensuring the sustainable development of agricultural enterprises]. Kharkiv: Visnyk KhNTUSG: ekonomichni nauky [Bulletin of KhNTUA: economic sciences], vol. 191, pp. 222-236.

6. Zaika S.O., Hridin O.V. (2016) Upravlinnia intelektualnym kapitalom yak chynnyk zabezpechennia konkurentospromozhnosti pidpryiemstva [Management of intellectual capital as a factor in ensuring the competitiveness of the enterprise]. Kharkiv: Visnyk KhNTUSG: ekonomichni nauky '[Bulletin of KhNTUA: economic sciences], vol. 177, pp. 176-186.

7. Kybanov A.Ya. (2013) Sostavlyayushchiye organizatsionno-ekonomicheskogo mekhanizma formirovaniya sistemy upravleniya personalom organizatsii [Components of the organizational and economic mechanism for the formation of the organization's personnel management system]. Scientific-methodical electronic journal "Concept", vol. 3, pp. 2896-2900.

8. Kolot A.M. (1998) Motyvatsiia, stymuliuvannia i otsinka personalu [Motivation, stimulation and evaluation of staff]. Tutorial.

Kyiv: KNEU, p. 224.

9. Kolot A.M. (2005) Motyvatsiia personalu [Staff motivation]. Tutorial. Kyiv: KNEU. (in Ukrainian)

10. Kulipanov K. (2009) Motyvatsiia i otsinka personalu [Motivation and evaluation of staff]. Tutorial. Kyiv: Znannia-Pres. (in Ukrainian)

11. Mazniev H.Ye., Zaika S.O., Hridin O.V. (2016) Antykryzove upravlinnia yak sfera biznes-administruvannia [Crisis management as a field of business administration]. Naukovyi visnyk UzhNU. Seriia: Mizhnarodni ekonomichni vidnosyny ta svitove hospodarstvo» [Scientific Bulletin of Uzhhorod National University. Series: International Economic Relations and the World Economy], vol. 10, pp. 25-32.

12. Mazniev H.Ye., Zaika S.O., Hridin O.V. (2016) Sutnisna kharakterystyka intelektualnoho kapitalu [Essential characteristics of intellectual capital]. Scientific and practical journal "Black Sea Economic Studies", vol. 10, pp. 36-47.

13. Meskon M.Kh. (2000) Osnovy menedzhmenta [Management Basics]. Moscow: Delo. (in Russian)

14. Nykyforenko V.H. (2013) Upravlinnia personalom [Staff management]. Odesa: Atlant. (in Ukrainian)

15. Uaitly F. (2005) Motyvatsiia [Motivation]. Moscow: Vil'yams. (in Russian)

16. Klimova E.A. (ed.) (2015) Upravlenie motivacyiej vuzov [Motivation management]. Moscow: UNITY-DANA. (in Russian)

17. Ustilovska A.S. (2017) Motyvatsiia personalu yak odyn z osnovnykh instrumentiv uspishnoho upravlinnia personalom [Staff motivation as one of the main tools for successful personnel management], «Molodyi vchenyi», no. 4.4 (44.4), pp. 112-115.

\section{Список використаних джерел:}

1. Zaika Svitlana, Gridin Oleksandr, Kuskova Svitlana. The concepts and the essence of intellectual capital. Науково-практичний журнал «Причорноморські економічні студіï». 2020. Вип. 52. С. 28-39.

2. Zaika S., Gridin O. Human capital development in the agricultural economy sector. Technology audit and production reserves. 2020. № 1/4(51). Pp. 30-36. DOI: 10.15587/2312-8372.2020.194444 URL: http://journals.uran.ua/tarp/article/view/194444 (дата звернення: 20.11.2020).

3. Бойко Ю.И., Коробкина М.А. Мотивация и стимулирование труда как объективный фактор повышения конкурентоспособности предприятия в условиях становления и развития рыночных отношений. Научно-методический электронный журнал «Кониепт». 2016. T. 2. С. 236-240. URL: http://e-koncept.ru/2016/46061.htm (дата звернення: 20.11.2020).

4. Бондар В. Еволюція мотивації як функції управління. Наукові записки. Серія «Культура та соціальні комунікації». Острог : Видавництво Національного університету «Острозька академія», 2010. Вип. 2. С. 175-185.

5. Заїка С.О. Мотивація та стимулювання як чинники забезпечення стійкого розвитку сільськогосподарських підприємств. Вісник ХНТУСГ: економічні науки. 2018. Вип. 191. С. 222-236.

6. Заїка С.О., Грідін О.В. Управління інтелектуальним капіталом як чинник забезпечення конкурентоспроможності підприємства. Вісник ХНТУСГ: Економічні науки. Харків : ХНТУСГ, 2016. Вип. 177. С. 176-186.

7. Кибанов А.Я. Составляющие организационно-экономического механизма формирования системы управления персоналом организации. Научно-методический электронный журнал «Концепт». 2013. Т. 3. С. 2896-2900.

8. Колот А.М. Мотивація, стимулювання й оцінка персоналу : навчальний посібник. Київ : КНЕУ, 1998. 224 с.

9. Колот А.М. Мотивація персоналу : підручник. Київ : КНЕУ, 2005. 337 с.

10. Куліпанов К.А. Мотивація і оцінка персоналу : навчальний посібник. Київ : Знання-Прес, 2009. 138 с.

11. Мазнєв Г.С., Заїка С.О., Грідін О.В. Антикризове управління як сфера бізнес-адміністрування. Науковий вісник УжНУ. Серія: Міжнародні економічні відносини та світове господарство». 2016. Вип. 10. С. 25-32.

12. Мазнєв Г.С., Заїка С.О., Грідін О.В. Сутнісна характеристика інтелектуального капіталу. Науково-практичний журнал «Причорноморські економічні студї». 2016. Вип. 10. С. 36-47.

13. Мескон М.Х., Альберт М., Хедоури Ф. Основы менеджмента / пер. с анг. Москва : Дело, 2000. 704 с.

14. Никифоренко В.Г. Управління персоналом : навчальний посібник. Одеса : Атлант, 2013. 275 с.

15. Уайтли, Ф. Мотивация. Москва : Вильямс, 2005. 160 с.

16. Управление мотивацией : учеб. пособие для вузов / пер. с англ., под ред. проф. Е.А. Климова / Ричи Ш., Мартин П. Москва : ЮНИТИ-ДАНА, 2015. 399 с.

17. Устіловська А.С. Мотивація персоналу як один з основних інструментів успішного управління персоналом. «Молодий вчений». 2017. № 4.4 (44.4). С. 112-115. 


\section{СУТНІСТЬ І ПРОБЛЕМИ МОТИВАЦЇ̈ ЯК ФАКТОРА РОЗВИТКУ СУЧАСНИХ ПІДПРИЕМСТВ}

В останній чверті XVIII століття А. Сміт вперше зауважси про необхідність мотивації пращі персоналу підприсмств та дана кониепція не втратила актуальності і до сьогодні. Адже ефективний розвиток сучасних інновачійних підприсмств залежить від мотиваиії трудової діяльності його співробітників. Тільки розуміючи те, щзо спонукає працівника до роботи, які мотиви є рушійною силою його вчинків, можна заснувати ефективну систему управління. Значення мотивації у виконанні персоналом підприємства своїх посадових обов'язків полягає у визначенні намагань співробітників, впливі на їх сумлінність, наполегливість, відповідальність і ретельність. Вмотивованість працівників підприємства є визначальним чинником забезпечення його ефективного розвитку, оскільки завдяки їй у співробітників з'являється бажання праџювати з самовіддачею, зростає зачікавленість в ефективності результатів спільної роботи. Тільки ефективна система стимулювання і мотивації праці може спонукати кожного співробітника якісно виконувати посадові обов'язки та продуктивно працювати для досягнення бажаних иілей підприємства. Мета дослідження полягала в обгрунтуванні теоретичних аспектів вдосконалення управління мотивацією персоналу сучасних інноваційних підприємств. Теоретичною основою дослідження були наукові праці вітчизняних $i$ зарубіжних вчених в сфері мотивачї персоналу та розвитку сучасних підприємств інновачійного типу. Крім того було опрацьовано роботи зарубіжних і вітчизняних науковців, які досліджують питання системного підходу до управління мотивачією персоналу сучасних інновачійних підприємств. Вивчення системи мотивації вказало, щчо найбільш проблемним питанням є виявлення мотиваційних факторів, які можуть впливати на збільшення продуктивності праці персоналу сучасних підприємств. Встановлено, щзо мотиваційні інструменти для сучасних інноваційних підприємств можуть значно відрізнятися. Отже, для забезпечення сталого розвитку $i$ зростання рівня конкурентоспроможності підприємств керівництву потрібно приділяти значну увагу управлінню мотивацією працівників і ї̈ специфічним особливостям, характерним для певної галузі національної економіки.

Ключові слова: мотивачія, персонал підприємства, управління мотивацією, мотивуючі чинники, сучасні інновачійні підпиємства. 